\title{
Inhibitory Effects of Cancer Cell Proliferation by Novel Histone Deacetylase Inhibitors Involve p21/WAF1 Induction and $\mathbf{G}_{2} / \mathbf{M}$ Arrest
}

\author{
Taishi Maeda, ${ }^{a}$ Yasuo Nagaoka,,${ }^{a, b}$ Yuki Kawai, ${ }^{a}$ Nobumasa TAKagaki, ${ }^{c}$ Chikako Yasuda, ${ }^{c}$ \\ Shingo Yogosawa, ${ }^{c}$ Yoshihiro Sowa, ${ }^{c}$ Toshiyuki SaKaI, ${ }^{c}$ and Shinichi Uesato $*, a, b$ \\ ${ }^{a}$ Department of Biotechnology, Faculty of Engineering, Kansai University; ${ }^{b}$ High Technology Researach Center, Kansai \\ University; Suita, Osaka 564-8680, Japan: and ${ }^{c}$ Department of Molecular-Targeting Cancer Prevention, Kyoto \\ Prefectural University of Medicine, Graduate School of Medical Science; Kyoto 602-8566, Japan. \\ Received November 24, 2004; accepted February 2, 2005
}

Two compounds were synthesized which have a structural component other than those of our new series histone deacetylase (HDAC) inhibitors to determine the structure-activity relationship. It was also examined whether the inhibitory effects on cancer cell proliferation by HDAC inhibitors involve p21/WAF1 induction and $G_{1}$ or $G_{2} / M$ arrest in p53-mutated MG63 human osteosarcoma cells as do other HDAC inhibitors. It was demonstrated that inhibitors with the 2-naphthylcarbonyl group and hydroxamic acid at both termimal sides as well as the phenylene component at the center of molecule markedly induce the p21/WAF1 protein by stimulating p21/WAF1 gene promoter activity. Furthermore, cell cycle analysis revealed that these compounds arrest MG63 cells in the $G_{2} / M$ phase.

Key words histone deacetylase inhibitor; p21/WAF1; MG63 cell; HCT116 cell; $\mathrm{G}_{2} / \mathrm{M}$ phase; cell cycle arrest

Histone acetyltransferases (HATs) and histone deacetylases (HDACs) play a crucial role in gene expression through reversible acetylation and deacetylation of histones. HAT-mediated hyperacetylation of lysine residues in the N-terminal tails of core histones loosens the histone-DNA binding and activates gene transcription. In contrast, HDAC-catalyzed deacetylation of acetylated lysine residues leads to tight histone-DNA binding, which restricts the access of transcriptional factors. ${ }^{1-3)}$ These enzymes are known to correlate with cell cycle progression, and their deregulation is associated with tumorigenesis. ${ }^{4-6)}$ HDAC inhibitors appear to be attractive new antitumor candidates because they are expected to suppress the cell cycle progression of human tumor cells and cause apoptosis by inducing the expression of cell cycle-arresting genes such as $\mathrm{p} 21 / \mathrm{WAF}^{7)}$ and GADD45. ${ }^{8)}$ Recently, X-ray crystallographic analysis has disclosed the interaction mode between the HDAC-like protein (HDLP) from the bacterium Aquifex aeolicus and the natural HDAC inhibitor TSA from actinomyces; TSA binds inside the pocket of HDLP, making tight contacts with residues at the rim, walls, and bottom of the pocket. The zinc ion near the bottom is coordinated by the hydroxamic acid of TSA. ${ }^{9}$ For the design of a new series HDAC inhibitors, we chose a benzyl component for interaction with the walls of a HDAC pocket, a bicyclic arylcarbonyl component for capping the pocket, and the hydroxamic acid for capture of the zinc ion at the bottom. Among the synthesized HDAC inhibitors, compound 1 showed promising inhibitory efficacies against the proliferation of HCT116 human colorectal carcinoma cells $\left(\mathrm{IC}_{50} 0.7 \mu \mathrm{M}\right)$ and HDACs activities $\left(\mathrm{IC}_{50} 0.044 \mu \mathrm{M}\right)$ (Table 1). ${ }^{10)}$ Further improvement of the pharmacokinetic profile afforded the nitrogen-introduced compounds $2-\mathbf{4}$. These compounds were improved in water solubility. Compound $\mathbf{2}$ exhibited inhibitory activities stronger than those of suberoylanilide hydroxamic acid (SAHA) against a panel of cancer cells as well as the maximal $185 \% \mathrm{~T} / \mathrm{C}$ of survival rate in the experiments with P388 cell-inoculated mice. ${ }^{11)}$

In the present study, we synthesized two derivatives $\mathbf{5}$ and 6 with a structural component (2,6-naphthylene or thiol group) other than those of the HDAC inhibitors $\mathbf{1}-\mathbf{4}$ to determine whether these groups can be substitutes for phenylene and hydroxamic acid groups in $\mathbf{1 - 4}$, making contacts with the walls and zinc ion of the HDAC pocket, respectively. We also examined whether the inhibitory effects on cancer cell proliferation by the novel histone deacetylase inhibitors involve $\mathrm{p} 21 / \mathrm{WAF} 1$ induction and $\mathrm{G}_{1}$ or $\mathrm{G}_{2} / \mathrm{M}$ arrest as do other HDAC inhibitors through assessment of Western blot, luciferase, and cell cycle progression assays.

Chemistry Compounds $\mathbf{5}$ and $\mathbf{6}$ were synthesized in the following way (Chart 1): Condensation of methyl 6-amino-2naphthoate hydrochloride and phenylacetyl chloride in the presence of $\mathrm{Et}_{3} \mathrm{~N}$ gave $\mathbf{5 a}$, which, after conversion to carboxylic acid $\mathbf{5 b}$, was reacted with BOP-Cl and $O$-benzylhydroxyamine hydrochloride to give 5c. It was then hydrogenated over $10 \%$ Pd-C, yielding the desired 5. Condensation

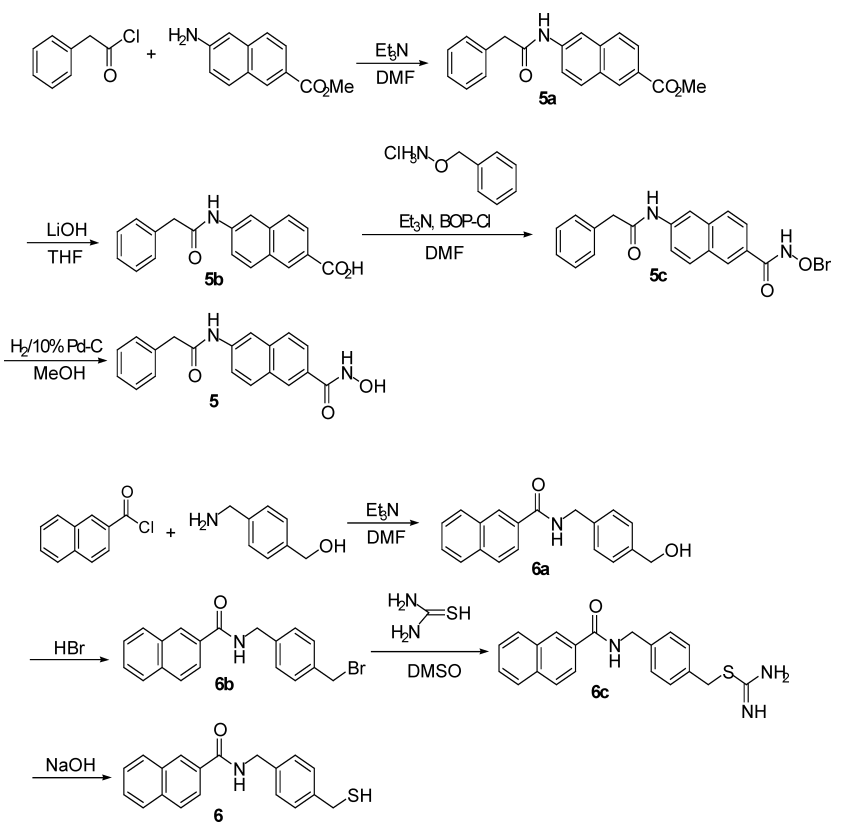

Chart 1. Synthetic Pathways of 5 and $\mathbf{6}$ 
of [4-(aminomethyl)phenyl]methanol and phenylacetyl chloride in the presence of $\mathrm{Et}_{3} \mathrm{~N}$ gave $\mathbf{6 a}$, which was treated with $\mathrm{HBr}$ to give benzyl brimide $\mathbf{6 b}$. Replacement reaction of bromine (6b) with thio-ureido (6c) followed by alkaline treatment yielded the desired $\mathbf{6}$.

\section{MATERIAL AND METHODS}

Melting points were determined on a Yanagimoto MP-32 micromelting point apparatus and are uncorrected. IR spectra were recorded on Shimadzu FTIR-8400 infrared spectrophotometer. Low-resolution (LR)-FAB-MS spectra were measured on a JEOL JMS-HX 100 instrument, whereas high-resolution (HR)- and LR-electron impact (EI)-MS spectra were measured on a JEOL The Tandem MStation JMS-700. ${ }^{1} \mathrm{H}-$ NMR spectra were recorded on JEOL EX-270 $(270 \mathrm{MHz})$ and JEOL EX-400 (400 MHz) instruments using tetramethylsilane as an internal standard. Analytical TLC and PLC were performed using Silica gel $60 \mathrm{~F}_{254}$ (Merck, 0.25 and $0.5 \mathrm{~mm}$, respectively) glass plates. Column chromatography was performed using Silica Gel 60 (70-230 mesh ASTM). TSA was purchased from Sigma-Aldrich Co.

Methyl 6-[(Phenylacetyl)amino]-2-naphthoate (5a) To a suspension of methyl 6-amino-2-naphthoate hydrochloride $(3.0 \mathrm{~g}, 14.9 \mathrm{mmol})$ in absolute DMF $(60 \mathrm{ml})$ were added $\mathrm{Et}_{3} \mathrm{~N}$ $(8.3 \mathrm{ml}, 60.0 \mathrm{mmol})$ and phenylacetyl chloride $(2.16 \mathrm{ml}$, $16.4 \mathrm{mmol})$. The mixture was stirred at room temperature overnight. After being evaporated, the residue was dissolved in $\mathrm{CHCl}_{3}(200 \mathrm{ml})$ and washed successively with $1 \mathrm{~N} \mathrm{HCl}$ $(3 \times 50 \mathrm{ml})$, saturated $\mathrm{NaHCO}_{3}(3 \times 50 \mathrm{ml})$, and brine $(3 \times$ $50 \mathrm{ml}$ ). The organic layer was dried and concentrated to dryness. The resulting residue was recrystallized from $\mathrm{CHCl}_{3}-n$ hexane to give the pure compound 5a $(1.3 \mathrm{~g}, 4.3 \mathrm{mmol}$, $30.0 \%$ yield). $\mathrm{mp} 177.5-180.9^{\circ} \mathrm{C}$. IR $(\mathrm{KBr}) \mathrm{cm}^{-1}: 3031$, 1714, 1656, 1584, 1238, 1097, 775, 545. ${ }^{1} \mathrm{H}-\mathrm{NMR}\left(\mathrm{CDCl}_{3}\right)$ $\delta: 3.38\left(2 \mathrm{H}, \mathrm{d}, J=5.9 \mathrm{~Hz}, \mathrm{PhCH}_{2}\right), 3.95\left(3 \mathrm{H}, \mathrm{s}, \mathrm{CO}_{2} \mathrm{CH}_{3}\right)$, $7.33-8.20\left(11 \mathrm{H}, \mathrm{m}\right.$, arom. $\left.\mathrm{H}_{11}\right), 8.50\left(1 \mathrm{H}, \mathrm{s}, \mathrm{CH}_{2} \mathrm{CON} \underline{\mathrm{H}}\right)$; EI-MS $m / z: 319\left(\mathrm{M}^{+}\right), 201,170,91$; HR-EI-MS $m / z$ : 319.1207 (Calcd for $\mathrm{C}_{20} \mathrm{H}_{17} \mathrm{NO}_{3}: 319.1208$ ).

6-[(Phenylacetyl)amino]-2-naphthoic Acid (5b) $\mathrm{LiOH}$ $1 \mathrm{~m}(7.8 \mathrm{ml}, 7.8 \mathrm{mmol})$ was added to a solution of $\mathbf{5 a}(1.1 \mathrm{~g}$, $3.5 \mathrm{mmol})$ in a mixture of water $(0.5 \mathrm{ml})$ and THF $(15.1 \mathrm{ml})$, and the mixture was stirred at room temperature overnight. After evaporation of THF, the residual water solution was adjusted to $\mathrm{pH} 3$ with $1 \mathrm{~N} \mathrm{HCl}$. The resulting precipitate was filtered off and washed with water to give the pure compound 5b ( $1.0 \mathrm{~g}, 3.3 \mathrm{mmol}, 94 \%$ yield $) . \mathrm{mp} 361.1-363.5^{\circ} \mathrm{C}$. IR (KBr) cm ${ }^{-1}$ : 3031, 1651, 1611, 1546, 1392, 1261, 925, 786. ${ }^{1} \mathrm{H}-\mathrm{NMR}\left(\mathrm{CD}_{3} \mathrm{OD}\right) \delta: 4.45\left(2 \mathrm{H}, \mathrm{s}, \mathrm{PhCH}_{2}\right), 7.94-8.98$ $\left(11 \mathrm{H}, \mathrm{m}\right.$, arom. $\left.\mathrm{H}_{11}\right)$. EI-MS m/z: $305\left(\mathrm{M}^{+}\right), 187,91,44$; HREI-MS m/z: 305.1025 (Calcd for $\mathrm{C}_{19} \mathrm{H}_{15} \mathrm{NO}_{3}: 305.1052$ ).

$\boldsymbol{N}$-(Benzyloxy)-6-[(phenylacetyl)amino]-2-naphthamide (5c) To a suspension of $O$-benzylhydroxylamine hydrochloride $(0.31 \mathrm{~g}, 1.97 \mathrm{mmol})$ in absolute DMF $(8.2 \mathrm{ml})$ were added 5b $(0.50 \mathrm{~g}, 1.6 \mathrm{mmol}), \mathrm{BOP}-\mathrm{Cl} \quad(0.50 \mathrm{~g}$, $1.96 \mathrm{mmol})$, and $\mathrm{Et}_{3} \mathrm{~N}(0.67 \mathrm{ml}, 4.8 \mathrm{mmol})$. The mixture was stirred at room temperature overnight. After being evaporated, the residue was dissolved in $\mathrm{CHCl}_{3}(100 \mathrm{ml})$ and washed successively with $1 \mathrm{~N} \mathrm{HCl}(3 \times 20 \mathrm{ml})$, saturated $\mathrm{NaHCO}_{3}(3 \times 20 \mathrm{ml})$, and brine $(3 \times 20 \mathrm{ml})$. The organic layer was dried over $\mathrm{Na}_{2} \mathrm{SO}_{4}$ and concentrated. The resulting residue was recrystallized from EtOAc to give the pure compound 5c $(0.15 \mathrm{~g}, 0.37 \mathrm{mmol}, 23 \%$ yield $)$. mp $229.6-$ $232.1^{\circ} \mathrm{C}$. IR $(\mathrm{KBr}) \mathrm{cm}^{-1}: 3292,1643,1537,1313,1228$, $1028,812,696 .{ }^{1} \mathrm{H}-\mathrm{NMR}\left(\mathrm{DMSO}-d_{6}\right) \delta: 3.31(2 \mathrm{H}, \mathrm{d}, J=5.9$ $\left.\mathrm{Hz}, \mathrm{PhCH}_{2}\right), 4.95\left(2 \mathrm{H}, \mathrm{s}, \mathrm{OCH}_{2}\right), 7.22-8.36(16 \mathrm{H}, \mathrm{m}$, arom. $\left.\mathrm{H}_{16}\right), 10.55(1 \mathrm{H}, \mathrm{t}, J=5.9 \mathrm{~Hz}, \underline{\mathrm{HOH}}), 11.85(1 \mathrm{H}, \mathrm{s}$, $\left.\mathrm{CH}_{2} \mathrm{CONH}\right)$. EI-MS $m / z 410\left(\mathrm{M}^{+}\right), 395,304,186,91$. HREI-MS $m / z$ : 410.1640 (Calcd for $\mathrm{C}_{25} \mathrm{H}_{22} \mathrm{~N}_{2} \mathrm{O}_{3}$ : 410.1630).

N-(Hydroxy)-6-[(phenylacetyl)amino]-2-naphthamide (5) Ten percent $\mathrm{Pd}-\mathrm{C}(77 \mathrm{mg})$ was added to a solution of 5c $(0.10 \mathrm{~g}, 0.24 \mathrm{mmol})$ in $\mathrm{MeOH}(30 \mathrm{ml})$, and the mixture was stirred under $\mathrm{a}_{2}$ atmosphere overnight. The catalyst was removed by filtration and washed successively with $\mathrm{MeOH}$ and $\mathrm{CHCl}_{3}$. The combined filtrate was evaporated to give pure compound 5 (67.4 mg, $0.21 \mathrm{mmol}, 87.5 \%$ yield). mp 230.0 $230.5^{\circ} \mathrm{C}$ (dec.). IR (KBr) cm ${ }^{-1}: 3030,1651,1554,1023$, 898, 771. ${ }^{1} \mathrm{H}-\mathrm{NMR}$ (DMSO- $\left.d_{6}\right) \delta: 3.69(2 \mathrm{H}, \mathrm{d}, J=5.9 \mathrm{~Hz}$, $\left.\mathrm{CH}_{2}\right), 7.22-8.34\left(11 \mathrm{H}, \mathrm{m}\right.$, arom. $\left.\mathrm{H}_{11}\right), 9.00(1 \mathrm{H}, \mathrm{t}, J=5.9$ $\mathrm{Hz}, \mathrm{N} \underline{\mathrm{HOH}}), 10.46\left(1 \mathrm{H}, \mathrm{s}, \mathrm{CH}_{2} \mathrm{CON} \underline{\mathrm{H}}\right)$. FAB-MS $m / z: 321$ $\left(\mathrm{M}+\mathrm{H}^{+}\right), 277,185,93,75$; HR-FAB-MS $m / z: 321.1245$ (Calcd for $\mathrm{C}_{19} \mathrm{H}_{17} \mathrm{~N}_{2} \mathrm{O}_{3}: 321.1239$ ).

$\boldsymbol{N}$-[4-(Hydroxymethyl)benzyl]-2-naphthamide (6a) 2Naphthoyl chloride $(4.73 \mathrm{~g}, 21.8 \mathrm{mmol})$ was reacted with [4(aminomethyl)phenyl]methanol $(3.02 \mathrm{~g}, 22.0 \mathrm{mmol})$ in the presence of $\mathrm{Et}_{3} \mathrm{~N}(9.0 \mathrm{ml}, 88.3 \mathrm{mmol})$ in the same way as for 5a, yielding 6a $(3.86 \mathrm{~g}, 13.2 \mathrm{mmol}, 60.2 \%$ yield $) . \mathrm{mp}$ $163.0-164.0^{\circ} \mathrm{C}$. IR (KBr) cm ${ }^{-1}: 2886,1544,954,837,781$, 482. ${ }^{1} \mathrm{H}-\mathrm{NMR}\left(\mathrm{CD}_{3} \mathrm{OD}\right) \delta: 4.72\left(2 \mathrm{H}, \mathrm{s}, \mathrm{NHCH}_{2} \mathrm{Phe}\right), 4.80$ $\left(2 \mathrm{H}, \mathrm{s}, \mathrm{PheCH} \mathrm{H}_{2} \mathrm{OH}\right), 6.54\left(2 \mathrm{H}, \mathrm{m}\right.$, arom. $\left.\mathrm{H}_{2}\right), 7.36-7.39$ $\left(3 \mathrm{H}, \mathrm{m}\right.$, arom. $\left.\mathrm{H}_{3}\right), 7.50-7.64\left(2 \mathrm{H}, \mathrm{m}\right.$, arom. $\left.\mathrm{H}_{2}\right), 7.82-$ $7.86\left(2 \mathrm{H}, \mathrm{m}\right.$, arom. $\left.\mathrm{H}_{2}\right), 7.88-7.92\left(2 \mathrm{H}, \mathrm{m}\right.$, arom. $\left.\mathrm{H}_{2}\right)$. FABMS $m / z: 292\left(\mathrm{M}+\mathrm{H}^{+}\right), 277$, 185. HR-FAB-MS $m / z$ : 292.1340 (Calcd for $\mathrm{C}_{19} \mathrm{H}_{18} \mathrm{NO}_{2}: 292.1338$ ).

$\boldsymbol{N}$-[4-(Bromomethyl)benzyl]-2-naphthamide (6b) A mixture of $\mathbf{6 a}$ in $49 \%$ aqueous $\mathrm{HBr}$ was heated at $90^{\circ} \mathrm{C}$ for $10 \mathrm{~min}$. After cooling, the resulting precipitate was filtered off and washed with water to give pure compound $\mathbf{6 b}(1.72 \mathrm{~g}$, $4.9 \mathrm{mmol}, 90.6 \%$ yield). $\mathrm{mp} 171.2-177.0^{\circ} \mathrm{C}$ (dec.). IR $(\mathrm{KBr}) \mathrm{cm}^{-1}: 1633,1548,1510,1232,871,838,742 .{ }^{1} \mathrm{H}-$ NMR $\left(\mathrm{DMSO}-d_{6}\right) \delta: 4.46\left(2 \mathrm{H}, \mathrm{s}, \mathrm{NHC}_{2}\right), 4.56(2 \mathrm{H}, \mathrm{s}$, $\left.\mathrm{CH}_{2} \mathrm{Br}\right), 6.90\left(4 \mathrm{H}, \mathrm{m}\right.$, arom. $\left.\mathrm{H}_{4}\right), 7.3-8.4\left(7 \mathrm{H}, \mathrm{m}\right.$, arom. $\left.\mathrm{H}_{7}\right)$. FAB-MS $m / z: 354\left(\mathrm{M}+\mathrm{H}^{+}\right), 297,185,171,157,155$. HRFAB-MS $m / z$ : 354.0521 (Calcd for $\mathrm{C}_{19} \mathrm{H}_{17} \mathrm{BrNO}$ : 354.0494).

4-[(2-Naphthoylamino)methyl]benzyl Imidothiocarbamate (6c) To a suspension of $\mathbf{6 b}$ in DMSO $(10 \mathrm{ml})$ was added thiourea $(123.8 \mathrm{~g}, 1.63 \mathrm{mmol})$, and the mixture was stirred at room temperature for $18 \mathrm{~h}$ and then lyophilized to remove the solvent. The resulting residue was recrystallized from $\mathrm{CHCl}_{3}$ to give pure compound $\mathbf{6 c}(1.3 \mathrm{~g}, 4.3 \mathrm{mmol}$, $30.0 \%$ yield). $\mathrm{mp} 217.3-218.7^{\circ} \mathrm{C}$. IR $(\mathrm{KBr}) \mathrm{cm}^{-1}: 3855$, 3845, 3726, 3622, 3008, 1537, 783. ${ }^{1} \mathrm{H}-\mathrm{NMR}$ (DMSO- $d_{6}$ ) $\delta$ : $3.51\left(2 \mathrm{H}, \mathrm{s}, \mathrm{CH}_{2}-\mathrm{S}\right), 4.53\left(2 \mathrm{H}, \mathrm{d}, J=5.6, \mathrm{CH}_{2} \mathrm{Br}\right), 7.3-9.2$ $\left(11 \mathrm{H}, \mathrm{m}\right.$, arom. $\left.\mathrm{H}_{11}\right)$. FAB-MS $m / z: 350\left(\mathrm{M}+\mathrm{H}^{+}\right)$. HR-FABMS $m / z$ : 350.1342 (Calcd for $\mathrm{C}_{20} \mathrm{H}_{20} \mathrm{~N}_{3} \mathrm{OS}: 350.1327$ ).

$\boldsymbol{N}$-[4-(Sulfanylmethyl)benzyl]-2-naphthamide (6) A suspension of $6 \mathrm{c}$ in aqueous $6 \% \mathrm{NaOH}$ was refluxed for $8 \mathrm{~h}$. After cooling, the solution was adjusted to $\mathrm{pH} 3$ with $\mathrm{HCl}$ $6 \mathrm{M}$. The resulting precipitate was filtered off and washed with water to give pure compound $6(51 \mathrm{mg}, 0.17 \mathrm{mmol}$, $63.4 \%$ yield). $\mathrm{mp} 213.4-216.3^{\circ} \mathrm{C}$. IR $(\mathrm{KBr}) \mathrm{cm}^{-1}: 3303$, 1695, 1639, 1546, 1508, 1417, 1355, 1313, 831, 781, 738. 
${ }^{1} \mathrm{H}-\mathrm{NMR}\left(\mathrm{DMSO}-d_{6}\right) \delta: 3.76\left(2 \mathrm{H}, \mathrm{s}, \mathrm{CH}_{2} \mathrm{SH}\right), 4.51(2 \mathrm{H}, \mathrm{d}$, $\left.J=6.0 \mathrm{~Hz}, \mathrm{NHC}_{2}\right), 7.2-9.3\left(11 \mathrm{H}, \mathrm{m}\right.$, arom. $\left.\mathrm{H}_{11}\right)$. FAB-MS $m / z: 308\left(\mathrm{M}+\mathrm{H}^{+}\right)$; HR-FAB-MS $m / z: 308.1090$ (Calcd for $\mathrm{C}_{19} \mathrm{H}_{18}$ NOS: 308.1109).

Evaluation of Histone Deacetylase Inhibitory Activities Partial purification of HDACs and measurement of inhibitory activities of test compounds against HDACs using $\left[{ }^{3} \mathrm{H}\right]-$ acetylated histones were performed according to the procedure by Mori et al. ${ }^{12)} \mathrm{IC}_{50}$ values in Table 1 represent the molar concentrations $(\mu \mathrm{M})$ required to inhibit the HDACs by $50 \%$.

Cell Culture HCT116 cells (purchased from the ATCC) were cultured in McCoy's 5a medium (Invitrogen) supplemented with 10\% fetal bovine serum (FBS), streptomycin $2.5 \mu \mathrm{g} / \mathrm{ml}$, and penicillin $2.5 \mathrm{units} / \mathrm{ml}$ at $37^{\circ} \mathrm{C}$ in a humidified atmosphere of $5 \% \mathrm{CO}_{2}$. Cells were passaged every $2 \mathrm{~d}$ into $60-\mathrm{mm}$ dishes by washing twice with phosphatebuffered saline (PBS) and incubated with $0.25 \%$ trypsin and $0.03 \%$ EDTA for $5 \mathrm{~min}$ at $37^{\circ} \mathrm{C}$ prior to resuspension in growth medium. MG63 human osteosarcoma cells (kindly provided by Dr. Y. Yanase, Wakayama Medical College) were cultured in Dulbecco's modified Eagle's medium (Invitrogen) supplemented with $10 \% \mathrm{FBS}$, streptomycin $10 \mu \mathrm{g} / \mathrm{ml}$, and penicillin 10 units $/ \mathrm{ml}$ at $37^{\circ} \mathrm{C}$ in a humidified atmosphere of $5 \% \mathrm{CO}_{2}$. Cells were passaged every $3 \mathrm{~d}$ into 100 $\mathrm{mm}$ dishes by washing twice with PBS and incubated with $0.05 \%$ trypsin and $0.02 \%$ EDTA for $3 \mathrm{~min}$ at $37^{\circ} \mathrm{C}$ prior to resuspension in growth medium.

Evaluation of Growth Inhibition against HCT116 Cells Cells were plated in 96-well plates at densities of $1.0 \times 10^{5} / \mathrm{ml}$. On the same day, compounds were added, and the cells were cultured for $2 \mathrm{~d}$. After addition of WST-1 and 1-methoxy-5-methyl-phenazinium methylsulfate, the $\mathrm{OD}_{450}$ and $\mathrm{OD}_{630}$ were measured in the conventional way. ${ }^{11)}$

Analysis of Cell Cycle Progression Cells were removed from culture dishes by trypsinization and collected by centrifugation. After washing with PBS, cells were suspended in PBS containing $0.1 \%$ Triton X-100 to prepare nuclei. After the suspension was filtered through 50-nm nylon mesh, $0.1 \%$ RNase and $50 \mathrm{mg} / \mathrm{ml}$ propidium iodide were added. DNA contents in stained nuclei were analyzed with FACSCalibur (Becton Dickinson). The suspension of cells was analyzed for each DNA histogram. The number of stained nuclei in each phase was measured according to the Mod Fit $L T$ program in the FACSCalibur system.

Plasmid Transfection an Assessment of Luciferase Assay The human wild-type p21/WAF1 promoter, pWWP-
Luc, was a kind gift from Dr. B. Vogelstein. Transient transfection was performed at $60 \%$ confluency in 12-well titer plates with the calcium phosphate technique using Cellphect transfecting agent (Amersham-Pharmacia). Luciferase activities were measured using a luminometer, and were normalized for the amount of the protein in cell lysates. All experiments were carried out in triplicate.

Western Blot Analysis MG63 cells in 100-mm plates were treated with $\mathbf{1}-\mathbf{6}$ at the various concentrations indicated in DMEM for $24 \mathrm{~h}$. After the medium was aspirated, the cells were washed with cold PBS and ice-cold radioimmunoprecipitation assay (RIPA) buffer. Western blot analysis was performed using mouse monoclonal antibody recognizing p21 (PM15091A from Pharmingen) as the primary antibody. The signal was detected with a chemiluminescence system (ECL, Amersham-Pharmacia). Protein concentration was determined using the Bio-Rad Protein Assay Kit.

\section{RESULTS AND DISCUSSION}

Table 1 shows the inhibitory activities of $\mathbf{1}-\mathbf{6}$ against the proliferation of HCT116 cells as well as HDACs. Compounds $\mathbf{1}-\mathbf{4}$ had comparatively low $\mathrm{IC}_{50}$ values (HCT116, $0.7-3.9 \mu \mathrm{M}$; HDAC, $0.026-0.044 \mu \mathrm{M})$. However, replace-

Table 1. Inhibition against HCT116 Cell Growth and HDACs

Compd.

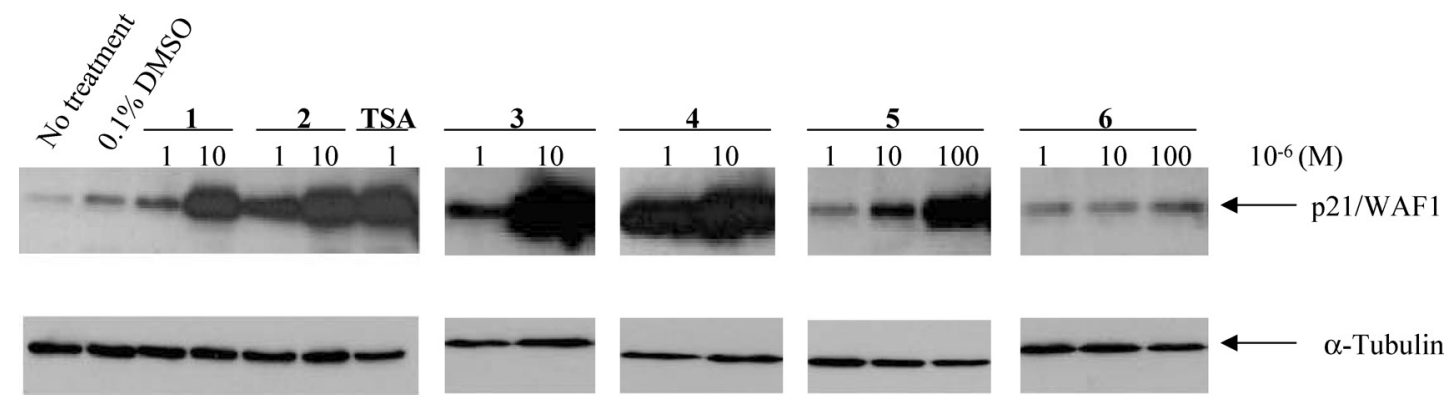

Fig. 1. Compound 1, 2, 3, or 4 Stimulates Endogenous p21/WAF1 Protein Expression

Lysates $(30 \mu \mathrm{g})$ of MG63 cells exposed to various concentrations of $\mathbf{1 , 2 , 3 , 4 , 5}$, or $\mathbf{6}$ as indicated or $0.1 \%$ DMSO for $24 \mathrm{~h}$ were examined using SDS-polyacrylamide gel electrophoresis and analyzed with immunoblotting using antibodies for p21/WAF1 and $\alpha$-tubulin. 
ment of the 1,4-phenylene and 2-naphthylcarbonyl group in $\mathbf{1}$ with the 2,6-naphthylene and phenylcarbonyl group in $\mathbf{5}$ as well as of hydroxamic acid in $\mathbf{1}$ with thiol in $\mathbf{6}$ resulted in much greater $\mathrm{IC}_{50}$ values.

We analyzed the effects of $\mathbf{1}-\mathbf{6}$ and TSA on $\mathrm{p} 21 / \mathrm{WAF} 1$ protein expression in MG63 cells. As shown in Fig. 1, treatment with $1-6$ induced $\mathrm{p} 21 / \mathrm{WAF} 1$ protein expression in a dose-dependent manner in Western blot analysis, although the protein levels induced by $\mathbf{5}$ and $\mathbf{6}$ were much lower than those by $\mathbf{1}-\mathbf{4}$, in consonance with the low HDAC and HCT116 inhibition of 5 and $\mathbf{6}$. In contrast, the level of alphatubulin was unaltered by each treatment (Fig. 1). We thus investigated whether these compounds could stimulate the activity of the p21/WAF1 gene promoter in cells transiently transfected with the 2.4-kb wild-type $\mathrm{p} 21 / \mathrm{WAF} 1$ promoterluciferase fusion plasmid pWWP-Luc. The p21/WAF1 gene promoter activity was markedly stimulated by $\mathbf{1}-\mathbf{4}$, in line with the enhancement of the protein expression, as illustrated in Fig. 2. Further, the effects of these compounds on cell cycle progression of MG63 cells were investigated by measuring the DNA content of nuclei of MG63 cells with flow cytometry. Exposure to $1 \mu \mathrm{M}$ of 4 or to $10 \mu \mathrm{M}$ each of 1, 2, and 3 for $24 \mathrm{~h}$ apparently decreased S-phase cells, whereas it caused accumulation of cells in the $\mathrm{G}_{2} / \mathrm{M}$ phase (Fig. 3). Interestingly, the levels of p21/WAF1 gene expression and $\mathrm{G}_{2} / \mathrm{M}$ phase accumulation were mutually correlated. We have so far shown that 21 /WAF1 is upregulated by HDAC inhibitors including TSA and sodium butyrate in MG63 cells; this was associated with $\mathrm{G}_{2} / \mathrm{M}$ arrest ${ }^{7)}$ It is also known that enhancement of p21/WAF1 causes $G_{1}$ arrest. $^{13)}$ p21/WAF1 inhibits cyclin-dependent kinase (CDK) activities such as CDK2, CDK4, or CDK6 promoting $\mathrm{G}_{1} / \mathrm{S}$-phase transition. ${ }^{13)}$ In addition to its role in $\mathrm{G} 1$ transition, $\mathrm{p} 21 / \mathrm{WAF} 1$ reaccumulates in nuclei near the $\mathrm{G}_{2} / \mathrm{M}$ boundary and causes a transient block in the late $\mathrm{G}_{2}$ phase. ${ }^{14)}$ In addition to CDK regulation, p21/WAF1 binds directly to PCNA, which is associated with
DNA replication and cell proliferation. ${ }^{15)}$

The observed increase in the p21/WAF1 level as well as the cell cycle arrest in the $\mathrm{G}_{2} / \mathrm{M}$ phase strongly suggest that $1-4$ are potent inhibitors of cell cycle progression. Although the p21/WAF1 gene is a p53-regulated one, ${ }^{16)}$ it was upregulated by $\mathbf{1}, \mathbf{2}, \mathbf{3}$, or 4 in the p53-mutated MG63 cells. Since the p53 gene is frequently mutated, ${ }^{17)}$ clarification of the p53-independent activating pathway of the p21/WAF1 gene might contribute to cancer therapy.

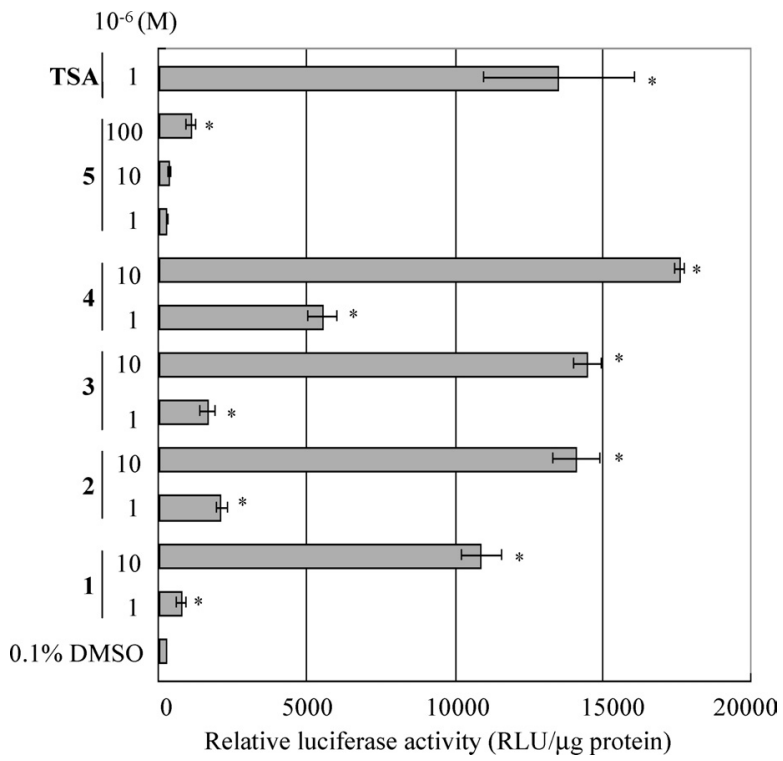

Fig. 2. Compoud 1, 2, 3, or 4 Activates p21/WAF1 Promoter Activity

MG63 cells were transiently transfected with the pWWP-Luc reporter plasmid, and luciferase activity was measured after incubation with or without various concentrations of $\mathbf{1}, \mathbf{2}, \mathbf{3}, \mathbf{4}$ or $\mathbf{5}$. Relative luciferase activity is shown as raw light units (RLU) in cell lysates $/ \mu \mathrm{g}$ of protein. All results are the mean \pm S.E. of at least three independent experiments, and the significant differences from the control $(0.1 \%$ DMSO $)$ were determined by Student's test and are indicated by an asterisk $(p<0.05)$.
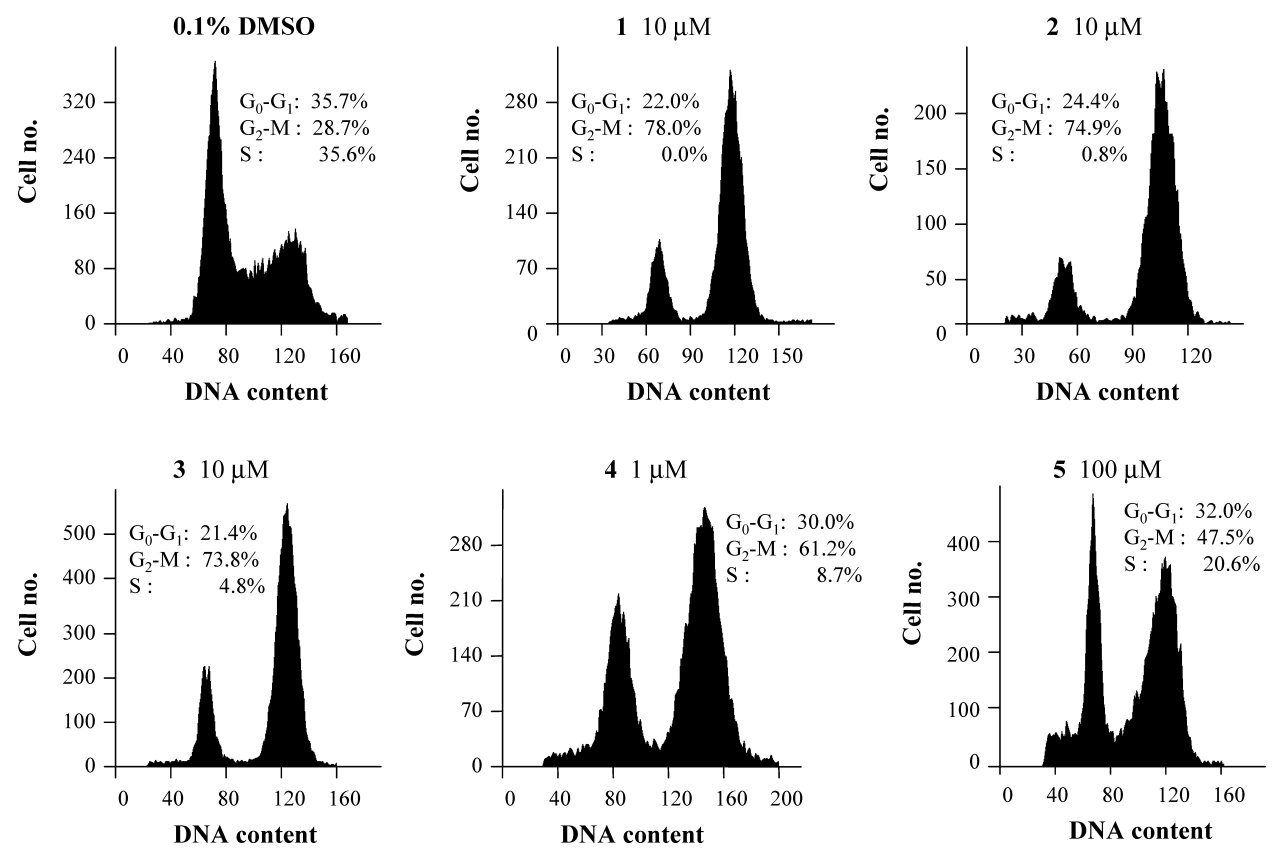

Fig. 3. Treatment with $\mathbf{1}, \mathbf{2}, \mathbf{3}$, or $\mathbf{4}$ Causes $\mathrm{G}_{2} / \mathrm{M}$ Arrest

MG63 cells were treated with or without various concentrations of $\mathbf{1}, \mathbf{2}, \mathbf{3}, \mathbf{4}$, or $\mathbf{5}$ as indicated for $24 \mathrm{~h}$, and their DNA content was analyzed using fluorescence flow cytometry. The percentages of the population in the $\mathrm{G}_{0} / \mathrm{G}_{1}, \mathrm{G}_{2} / \mathrm{M}$, and $\mathrm{S}$ phase are indicated. The experiment was repeated three times and representative histograms are shown. 
Acknowledgments Part of this research was financially supported by a Grant-in-Aid from the Japan Society for the Promotion of Science, Kansai University Special Aid for Promotion of Research and Education, 2002, and a Grant-inAid from the Ministry of Education, Culture, Sports, Science and Technology, Japan. We are grateful to Mr. H. Mori and Ms. T. Yamada for the HDAC inhibitory assay done at the Medical Biology Research Laboratories of Fujisawa Pharmaceutical Co., Ltd.

\section{REFERENCES}

1) Hassig C. A., Schreiber S. L., Curr. Opin. Chem. Biol., 1, 300-308 (1997).

2) Kouzarides T., Curr. Opin. Genet. Dev., 9, 40-48 (1999).

3) Strahl B. D., Allis C. D., Nature (London), 403, 41-45 (2000).

4) Wade P. A., Hum. Mol. Genet., 10, 693-698 (2001).

5) Cress W. D., Seto E., J. Cell. Physiol., 184, 1-16 (2000).

6) Marks P., Rifkind R. A., Richon V. M., Breslow R., Miller T., Kelly W. K., Nat. Rev. Cancer, I, 194-202 (2001).
7) Sowa Y., Orita T., Minamikawa S., Nakano K., Mizuno T., Nomura H., Sakai T., Biochem. Biophys. Res. Commun., 241, 142-150 (1997).

8) Hirose T., Sowa Y., Takahashi S., Saito S., Yasuda C., Shindo N., Furuichi K., Sakai T., Oncogene, 22, $7762-7773$ (2003).

9) Finnin M. S., Donigian J. R., Cohen A., Richon V. M., Rifkind R. A., Marks P. A., Breslow R., Pavletich N. P., Nature (London), 401, 188193 (1999).

10) Uesato S., Kitagawa M., Nagaoka Y., Maeda T., Kuwajima H., Yamori T., Bioorg. Med. Chem. Lett., 12, 1347-1349 (2002).

11) Maeda T., Nagaoka Y., Kuwajima H., Seno C., Maruyama S., Kaurotaki M., Uesato S., Bioorg. Med. Chem., 12, 4351-4360 (2004).

12) Mori H., Sakamoto K., Tsurumi Y., Takase S., Hino M., WO 00/21979 (2000) [Chem. Abstr., 132, 288796 (2000)].

13) Sherr C. J., Roberts J. M., Genes Dev., 9, 1149-1163 (1995).

14) Dulic V., Stein G. H., Far D. F., Reed S. I., Mol. Cell. Biol., 18, 546557 (1998)

15) Ando T., Kawabe T., Ohara H., Ducommun B., Itoh M., Okamoto T., $J$. Biol. Chem., 276, 42971- 42977 (2001).

16) El-Deiry W. S., Tokino T., Velculescu V. E., Levy D. B., Parsons R., Trent J. M., Lin D., Mercer W. E., Kinzler K. W., Vogelstein B., Cell, 75, 817-825 (1993).

17) Vogelstein B., Kinzler K. W., Cell, 70, 523-526 (1992). 